\title{
Alterations in Proteins and Amino Acids of the Nile Cyanobacteria Pseudanabaena limnetica and Anabaena wisconsinense in Response to Industrial Wastewater Pollution
}

\author{
Mostafa Mohamed El-Sheekh ${ }^{1 *}$, Ahmed Mohamed El-Otify ${ }^{2}$ and Hani Saber ${ }^{2}$ \\ ${ }^{I}$ Department of Botany; Faculty of Science; Tanta University; Tanta 31527 - Egypt. ${ }^{2}$ Department of Botany; Faculty \\ of Science; South Valley University; Aswan, 81528 - Egypt
}

\begin{abstract}
The effect of industrial wastewater on the Nile cyanobacteria Pseudanabaena limnetica and Anabaena wisconsinense was investigated. The data showed that $\mathrm{P}$. limnetica was more sensitive to pollution than A. wisconsinense. The treatments with different levels of wastewater exerted pronounced reductions in protein and amino acids content. SDS-PAGE analysis revealed that the cyanobacteria grown in the industrial wastewater showed induction in the synthesis of certain polypeptides and repression of others. The treatments of $\mathrm{P}$. limnetica with wastewater stimulated the appearance of six protein bands with molecular masses of 28, 30, 31, 32, 58 and 97 $k D a$. The same treatments caused the disappearance of 20,38 and $56 \mathrm{kDa}$. The structural protein pattern of the treated A. wisconsinense showed appearance of 16, 30, 170 and $230 \mathrm{kDa}$ and disappearance of $56 \mathrm{kDa}$. The treatment of the two investigated cyanobacteria with different levels of wastewater stimulated the biosyntheses of different amino acids and inhibited others.
\end{abstract}

Key words: amino acids, Anabaena, electrophoretic patterns, Nile cyanobacteria, protein, Pseudanabaena, wastewater

\section{INTRODUCTION}

Filamentous cyanobacteria are essential components of freshwater phytoplankton and have an outstanding role among the primary producers at the base of the food web in freshwater ecosystems. In such habitats, certain species of these phytoplankton components are sometimes allowed to flourish overwhelming various forms of aquatic biota and others to disappear or at least be suppressed. Here, it is necessary to emphasize that the discharge of industrial wastewater to the freshwater resources could be regarded as an abiotic factor that may be responsible for such fluctuations. Industrial wastewater may exert stimulatory or inhibitory influences upon the metabolic activities of different phytoplankton species, including filamentous cyanobacteria. The Nile water in Upper Egypt is subjected to industrial wastes rich with many pollutants. Therefore, it is essential to have a broad knowledge of the behavior of the Nile planktonic cyanobacteria in response to these pollutants. This can be achieved successfully based on data

*Author for correspondence: mostafaelsheekh@yahoo.com 
obtained from the laboratory studies concerning some metabolic activities of these species in a trial to understand how far these activities could be influenced by the pollution. The understanding of such effects on the Nile phytoplankton can help into future management strategy of the Nile water ecosystem in Egypt. Studies have shown that the treatment of phytoplankton with pollutants presented a reduction in the levels of protein within the cells of cyanobacteria (Mishra and Nanda, 1997; Abdel-Hameed et al., 2002; ElSheekh et al., 2005) and eukaryotic algae (Wong and Tam, 1984, Durrani and Khalil, 1989, Hammouda et al., 1995). However, the protein contents of some cyanobacteria (El-Naggar et al., 1999, El-Enany and Issa, 2000) and eukaryotic species of algae (Wong and Chan, 1990) were stimulated by low concentrations and inhibited by high concentrations of pollutants. Quantitatively, protein accumulation within the phytoplankton cells appeared to be related to the pollution stress caused by heavy metals (Angadi and Mathad, 1994, Xylaender and Braune, 1994). In this respect, different authors (Kobbia et al., 1985, Rai et al., 1994, Hart and Scaife, 1997) noticed that protein accumulation was stimulated by low and inhibited by high heavy metal contents of polluted wastewater. They explained the accumulation of protein at low heavy metal concentrations as one of the ways through which the algae can abolish their toxic effects, or to increase the utilization of carbohydrate through respiration. In addition, they attributed the inhibition of protein accumulation induced by high concentrations of heavy metals to the toxic action of these heavy metals on the enzymatic reactions responsible for protein biosynthesis. The appearance and disappearance of different proteins due to pollution stress were recorded in cyanobacteria (Arieli et al., 1989) and eukaryotic phytoplankton species (Osman et al., 2004). Free amino acids of the freshwater phytoplankton appear to be susceptible to pollution stress of industrial wastewater. Some amino acids metabolism are stimulated and certain others are inhibited due to pollution effects (Hammouda et al., 1995).

Phytoplankton species are quite different from each other in their response to various pollution stresses (Kott and Wachs 1964). The production and accumulation of some amino acids within the phytoplankton cells were reported in response to metal stress of pollutants (Kobbia et al., 1985; Poonguzhali and Rao, 1998). Similarly, the water polluted with insecticides could enhance or inhibit the biosynthesis of amino acids in cyanobacteria (El-Ayouty and Ezzat, 1991) and eukaryotic phytoplankton cells (Fathi, 2003). The aim of this study was to evaluate the effect of industrial wastewater on the qualitative and quantitative compositions of proteins and amino acids of the Nile cyanobacteria.

\section{MATERIAL AND METHODS}

\section{Isolation and cultivation of cyanobacteria}

Pseudanabaena limnetica and Anabaena wisconsinense were isolated from the Nile water in Upper Egypt at Aswan. Beijernick's nutritive medium (Stein, 1966) was used for isolation and cultivation of these cyanobacteria. Unialgal cultures of these cyanobacteria were obtained by repeating sub-culturing according to the method described by Pringsheim (1949). The cyanobacteria were grown in batch cultures at 29 $\pm 1^{\circ} \mathrm{C}$, continuously illuminated with fluorescent tubes at an incident light of $60 \mu \mathrm{mol} / \mathrm{m}^{2} / \mathrm{sec}$. and were supplied with sterilized dry air. The trichomes of $P$. limnetica and $A$. wisconsinense were cultivated in batch cultures treated with Kima factory effluents and grown for eight days using different concentrations $(0,2,4,6,8$ and $10 \%)$ of industrial wastewater. The heavy metals content of wastewater is shown in Table 1.

\section{Determinations of proteins}

Total proteins including soluble and insoluble fractions were measured using the method described by Lowry et al., (1951). The protein contents were measured spectrophotometrically and calculated from a calibration curve that was constructed using serum albumin. Soluble proteins content were estimated in extracts obtained in boiling distilled water. Insoluble protein fractions were determined in the water-insoluble residue remaining after the extraction of soluble protein. This residue was treated by $1 \mathrm{~N} \mathrm{NaOH}$ for at least 30 minutes in boiling water bath. Qualitative determinations of protein electrophoretic patterns were analyzed by Sodium Dodecyle Sulphate Polyacrylamide Gel Electrophoresis (SDS-PAGE) according to Laemmli (1970). In order to detect the variations in banding patterns under the influence of industrial waste water, proteins were simultaneously extracted from the cultures that were treated with wastewater and from the 
untreated culture by grinding the dry biomass of cyanobacteria with small pieces of glass and vortexing. These extractions were performed using the buffer solutions that contained 10\% SDS. Thereafter, the extracts were centrifuged at 4400xg for 15 minutes at $4{ }^{\circ} \mathrm{C}$. The samples were heated in a water bath $\left(96{ }^{\circ} \mathrm{C}\right)$ for $2-5$ minutes and loaded onto gel wells for electrophoresis (Bio Rad, Protean II XI Cell). Gels were run at $18 \mathrm{~mA}$ per gel for 6 hours at $4{ }^{\circ} \mathrm{C}$ in run buffer containing $0.025 \mathrm{M}$ Tris, $0.192 \mathrm{M}$ glycine and 0.1\% SDS. Protein bands were visualized by Coomassie Brilliant blue.

Table 1 - Heavy metal contents (mg/L) of the industrial wastewater that used for treatment of cyanobacteria cultures during the present investigation.

\begin{tabular}{cc}
\hline Heavy metal & value \\
\hline $\mathrm{Cd}$ & 0.08 \\
$\mathrm{Zn}$ & 0.09 \\
$\mathrm{Mn}$ & 0.05 \\
$\mathrm{Cr}$ & 0.02 \\
$\mathrm{Cu}$ & 0.02 \\
$\mathrm{Al}$ & 0.5 \\
$\mathrm{Fe}$ & 0.42 \\
$\mathrm{~Pb}$ & 0.76 \\
$\mathrm{Ni}$ & 0.05 \\
\hline
\end{tabular}

\section{Determinations of amino acids}

Total free amino acids were extracted from the cyanobacteria in boiled water and quantitatively estimated according to Moore and Stein (1948). For qualitative determinations, free amino acids were extracted according to the method adopted by Shad et al., (2002). Different amino acids were separated according to the method of Christian (1990) using HPLC system (HP1050) with a UV detector at $254 \mathrm{~nm}$.

\section{RESULTS}

\section{Influence of wastewater on protein contents}

Protein accumulations in the cells of $P$. limnetica (Fig. 1) and A. wisconsinense (Fig. 2) were significantly influenced by the treatment with different concentrations of industrial wastewater. In $P$. limnetica, the highest content of total protein $(3.17 \mu \mathrm{g} / \mathrm{ml})$ was recorded in the control culture at the end of experiment period. The application of different effluent concentrations induced remarkable decreases in the total protein contents by $43.2,61.2,63.7,71$ and $77.6 \%$ at the effluent concentrations of 2, 4, 6, 8 and $10 \%$, respectively as compared to control. The treatment with different wastewater concentrations exerted considerable decreases in the soluble protein contents. The level of soluble protein accumulation reached its maximum value of 1.52 $\mu \mathrm{g} / \mathrm{ml}$ in the untreated control culture. In the treated cultures, the values of soluble protein accumulations were gradually decreased with the increasing effluent concentrations. The lowest soluble protein value of $0.31 \mu \mathrm{g} / \mathrm{ml}$ was recorded in the cultures treated with $10 \%$ wastewater concentration. The insoluble protein contents were inhibited with the increasing concentration of the wastewater. The maximum inhibitory effect was observed at $10 \%$ concentration and reached 0.49 $\mu \mathrm{g} / \mathrm{ml}$ as compared with untreated control culture (1.65 $\mu \mathrm{g} / \mathrm{ml})$. In $A$. wisconsinense, pronounced decrease in the total protein contents was recorded due to the treatment with wastewater. The total protein contents ranged between $2.35 \mu \mathrm{g} / \mathrm{ml}$ in the control culture and $0.78 \mu \mathrm{g} / \mathrm{ml}$ in the culture treated with $10 \%$ wastewater concentration. The treatment of $A$. wisconsinense with different wastewater concentrations induced decreases in the soluble protein contents that reached $40.7 \%$ at $10 \%$ as compared with the control. The insoluble protein content in the control culture was $1.49 \mu \mathrm{g}$ $/ \mathrm{ml}$. The application of $10 \%$ of wastewater concentration induced a remarkable decrease in the insoluble protein content, which was 0.43 $\mu \mathrm{g} / \mathrm{ml}$ as compared with the control (Fig. 2). 


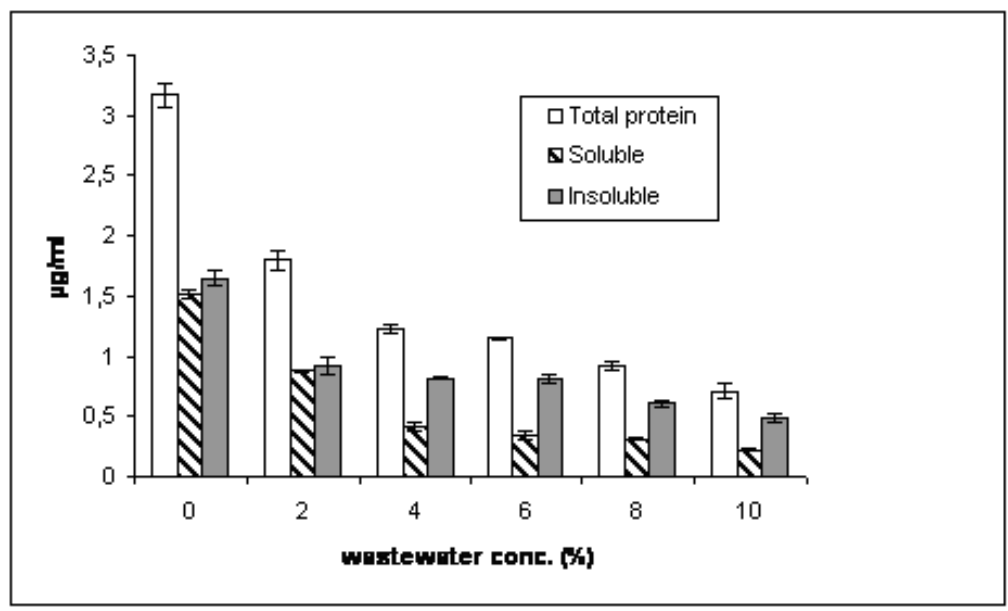

Figure 1 - Effect of different levels of industrial waste water on protein contents (mean values \pm SD) of Pseudanabaena lemnetica.

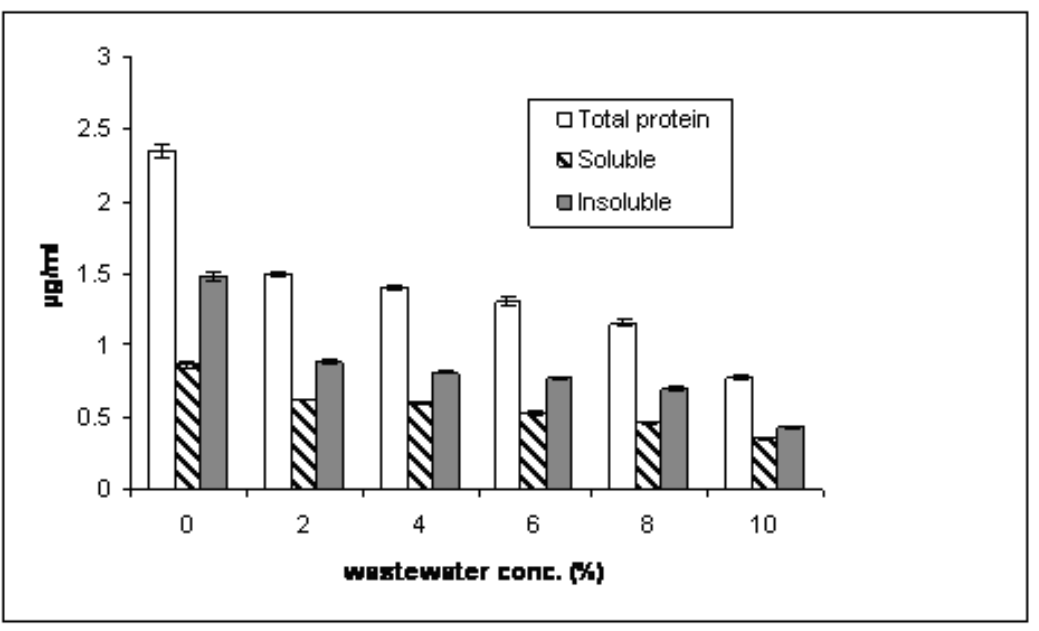

Figure 2 - Effect of different levels of industrial waste water on protein contents (mean values \pm SD) of Anabaena wisconsinense.

Wastewater stress either stimulated or inhibited the biosynthesis of some polypeptides in the cultures of the two investigated cyanobacteria. The effect of wastewater treatment on the structural protein pattern was obvious. The results in all the cultures treated with different wastewater concentrations were quite different from that of the untreated control culture. SDS-PAGE analysis of the total protein in P. limnetica (Fig. 3) showed the appearance of six protein bands of molecular masses of 28, 30, 31, 32, 58 and $97 \mathrm{kDa}$. These bands were not originally detected in the control.
Otherwise, the treatment of cultures with the wastewater was associated by the disappearance of proteins with apparent molecular masses of 20, 38 and $56 \mathrm{kDa}$ which appeared in the control track. In A. wisconsinense, SDS-PAGE (Fig. 4) showed the appearance of four protein bands of molecular masses of $16,30,170$ and $230 \mathrm{kDa}$ in the treated cultures which was undetected in the untreated control culture. On the other hand, the biosynthesis of one protein $(56 \mathrm{kDa})$ was suppressed due to the treatment with wastewater. 


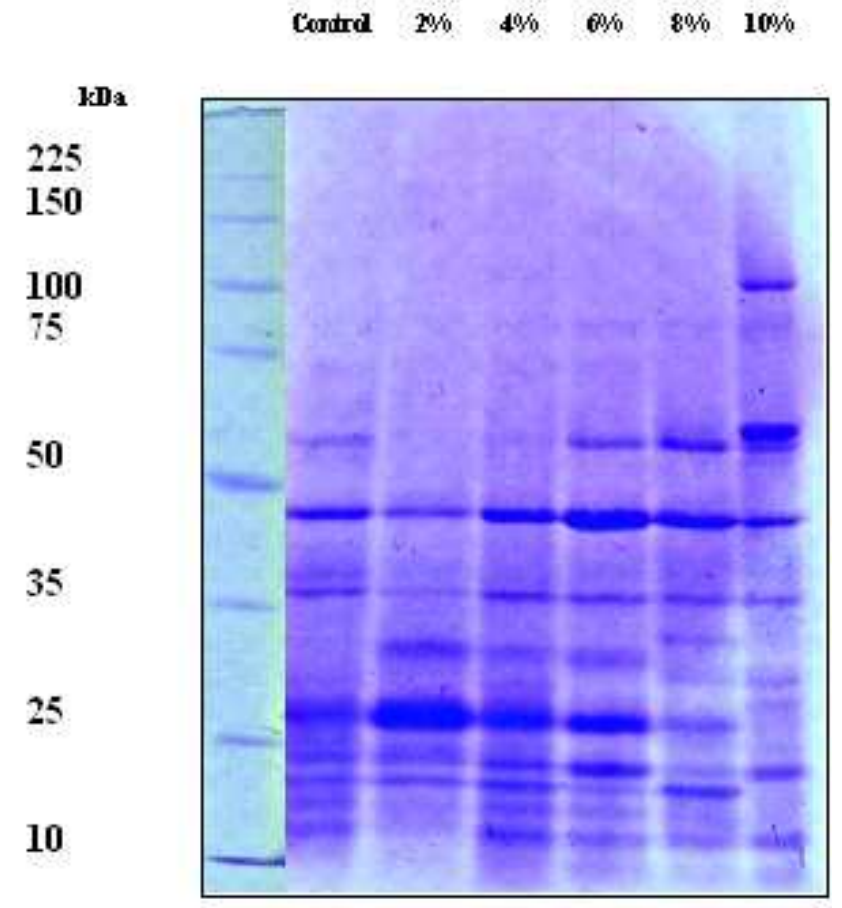

Figure 3 - Protein pattern in Pseudanabaena lemnetica grown under different levels of industrial wastewater and untreated control cultures.

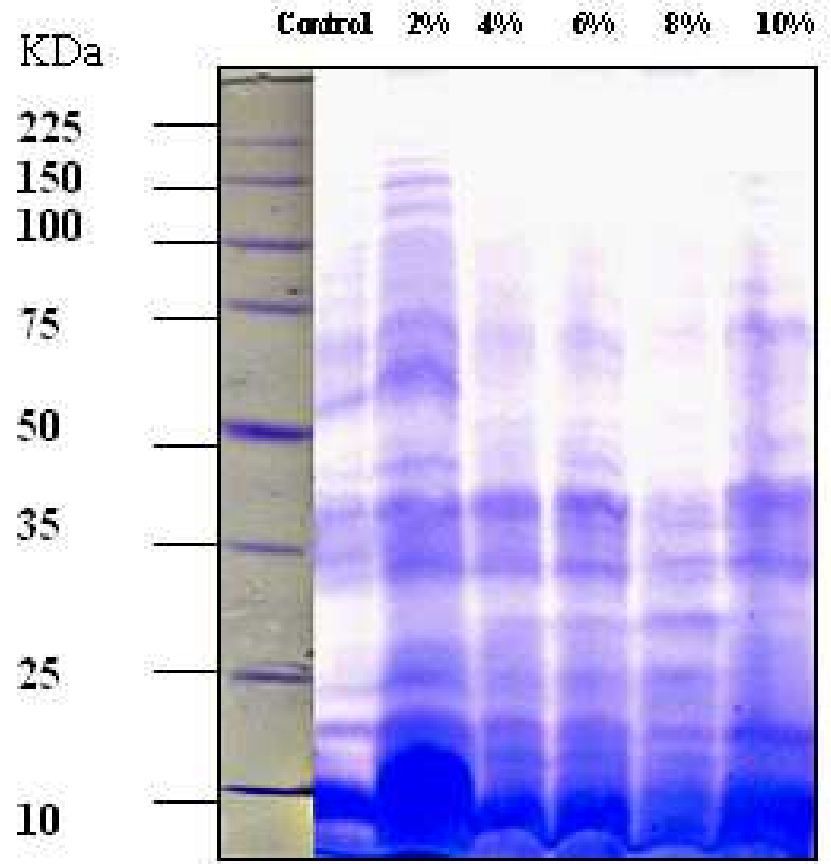

Figure 4 - Protein pattern in Anabaena wisconsinense grown under different levels of industrial wastewater and untreated control cultures. 
Influence of wastewater on aminoacids content The effect of industrial wastewater on the total free amino acids of the two investigated cyanobacteria was also studied. The increase in wastewater concentrations was accompanied by remarkable reductions in the accumulation of total free amino acids in the cultures of $P$. limnetica (Fig. 5) and A. wisconsinens (Fig.6).



Figure 5 - Effect of different levels of industrial wastewater on the accumulations of amino acids (mean values $\pm \mathrm{SD}$ ) in Pseudanabaena lemnetica.

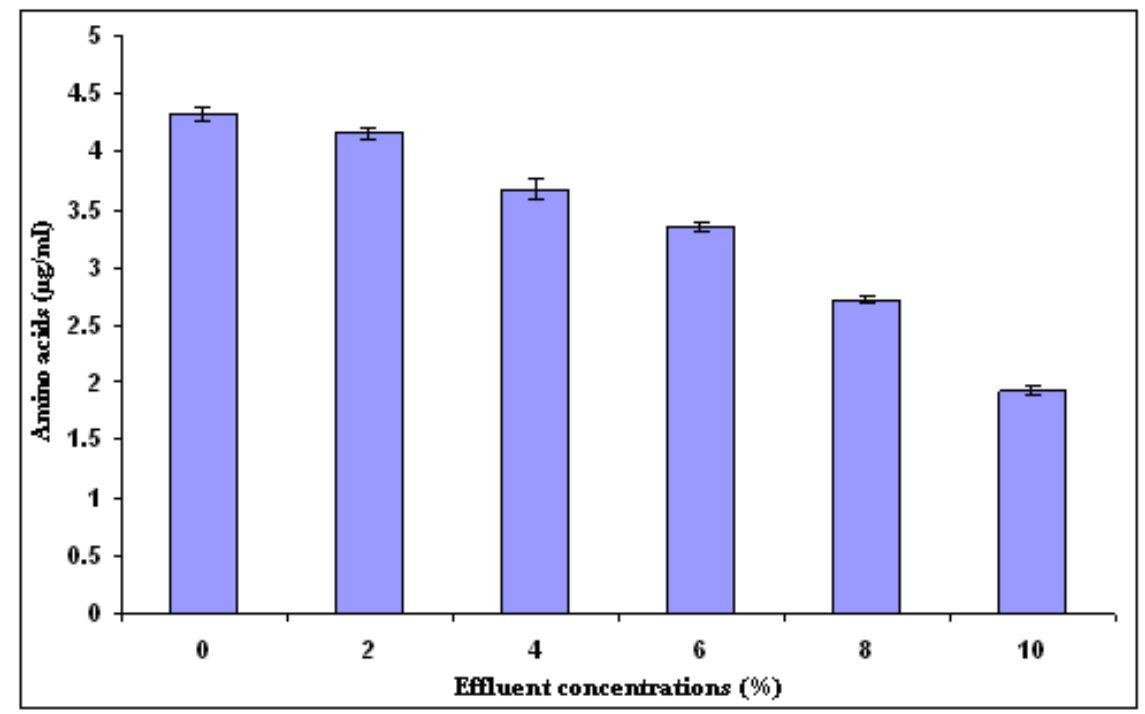

Figure 6 - Effect of different levels of industrial wastewater on the accumulations of amino acids (mean values $\pm \mathrm{SD}$ ) in Anabaena wisconsinense.

The amino acid contents of the untreated control culture reached $5.28 \mu \mathrm{g} / \mathrm{ml}$ in $P$. limnetica and $4.32 \mu \mathrm{g} / \mathrm{ml}$ in $A$. wisconsinense at the end of cultivation period. The reduction was more prominent at high than those at low waste concentrations. The treatment with $10 \%$ 
wastewater concentration reduced the amino acid contents by $21.2 \%$ in P. limnetica and by $44.4 \%$ in A. wisconsinense as compared with the control cultures. The changes in the qualitative compositions of amino acids within the cells of the two investigated cyanobacteria in response to low (4\%) and high (10\%) concentrations of industrial wastewater are shown in Table (2). Concerning the cultures of $P$. limnetica, the results revealed that the treatment with low concentration of $4 \%$ wastewater stimulated the biosynthesis of proline, tryptophane, cysteine and cystine. At the same time, it exhibited a reduction in threonine, methionine and valine biosynthesis. The application of high (10\%) wastewater concentration exerted inhibitory effects on the biosyntheses of threonine, proline, methionine and valine, but stimulated the biosynthesis of leucine and cysteine.

Table 2 - Variations of the amino acid qualitative and quantitative ( $\mu \mathrm{g} / \mathrm{gm}$ dry wt.) compositions within the cells of Pseudanabaena limnetica and Anabaena wisconsinense in response to industrial waste water treatment. A hyphen (-) denotes absence of the amino acid.

\begin{tabular}{lccccccc}
\hline \multirow{2}{*}{ Amino acids } & \multicolumn{3}{c}{ Pseudanabaena } & & \multicolumn{3}{c}{ Anabaena } \\
\cline { 2 - 4 } \cline { 6 - 8 } & Control & $\mathbf{4 \%}$ & $\mathbf{1 0 \%}$ & & Control & $\mathbf{4 \%}$ & $\mathbf{1 0 \%}$ \\
\hline Threonine & 4.46 & 4.29 & 1.89 & & 6.10 & 5.20 & 1.10 \\
Proline & 37.49 & 44.91 & 17.52 & & 49.92 & 57.07 & 12.16 \\
Methionine & 48.95 & 34.25 & 20.12 & & 51.80 & 76.85 & 14.94 \\
Valine & 161.39 & 143.02 & 98.30 & & 217.27 & 306.38 & 87.46 \\
Tryptophane & - & 63.90 & - & - & 195.49 & 78.05 \\
Leucine & - & - & 11.20 & & 35.47 & 39.30 & 10.93 \\
Cysteine & - & 7.33 & 2.66 & & 3.07 & 7.80 & 3.28 \\
Cystine & - & 3.87 & - & & - & - & - \\
\hline
\end{tabular}

For A. wisconsinense the application of $4 \%$ wastewater concentration stimulated the biosyntheses of proline, methionine, valine, tryptophane, leucine and cysteine. The treatment with the same concentration exerted an inhibition effect for threonine only. The application of a high concentration of $10 \%$ was associated with the enhancement of both tryptophane and cysteine assimilations. This high concentration inhibited the biosyntheses of threonine, proline, methionine, valine and leucine.

\section{DISCUSSION}

The data concerning the cell contents of proteins indicated that the two investigated cyanobacteria were significantly affected by the industrial wastewater. Protein contents of $P$. limnetica were more influenced by the wastewater than those of A. wisconsinense. The treatments with different concentrations of wastewater were accompanied by remarkable reductions in protein accumulations. These reductions could be an indirect effect of the wastewater on photosynthetic pigments that consequently could affect the protein biosynthesis (Strickland and Parsons, 1968). In agreement with these observations, the protein contents of different planktonic cyanobacteria were inhibited due to the treatment with wastewater (Canizares-Villanueva et al., 1995, Mishra and Nanda, 1997, Abdel-Hameed et al., 2002, El-Sheekh et al., 2005). In addition, the reduction in protein contents could be related to the presence of considerable concentrations of heavy metals in the wastewater. In this respect, Fernandez-Pinas et al., (1991) and El-Naggar et al., (1999) found that high concentrations of heavy metals were associated with reductions in the protein contents of different cyanobacteria. In contrast, El-Enany and Issa (2000) found that low levels of wastewater concentrations increased protein contents and the high levels were inhibitory to some nitrogen-fixing cyanobacteria species.

Pollution stress stimulated and inhibited the biosynthesis of different polypeptides within the cells of cyanobacteria grown in batch cultures. In the present investigation, the treatment of $P$. limnetica trichomes with the wastewater was accompanied by the appearance of six protein bands of relatively low molecular masses. Otherwise, the same treatment was associated with the disappearance of other three different protein bands. The treatment of $A$. wisconsinense cultures with the wastewater showed the appearance of two 
protein bands of low molecular masses and two bands of high molecular masses. In addition, the same treatment was associated by the disappearance of a single protein band of relatively low molecular mass. The stimulation of low molecular mass proteins in the two investigated species could be regarded as a possible tolerance mechanism to pollution stress exerted by the industrial wastewater. Similarly, Poonguzhali and Rao (1998); Perez-Rama et al., (2001); Osman et al., (2004) concluded that the induction of low molecular weight proteins was a common response to metal stress.

Pronounced reductions in the total free amino acid contents of the two investigated cyanobacteria were recorded due to the treatment with wastewater. Amino acid contents of P. limnetica were more affected than those of $A$. wisconsinense cultures. These results were quite in agreement with the data obtained by Canizares-Villanueva et al., (1995) during their studies on the planktonic cyanobacteria; Spirulina maxima and Phormidium sp. They reported that the amino acid contents of these cyanobacteria grown in synthetic media were higher than those grown in the wastewater. The reductions in amino acids content could be due to the relatively high salinity of the industrial wastewater of Kima factory. In this context, several investigators (Shafea, 1987, Desouky, 1990, Mohamed and Shafea, 1992, Galal, 1998, Abdel-Mawgoud, 2005) have related the reduction in free amino acids to high salinity treatments. The stimulation of biosyntheses of some free amino acids in the two investigated cyanobacteria could be regarded as a metabolic response (El-Naggar 1993, Wu et al., 1995) due to the presence of considerable amount of heavy metals in the wastewater. Generally, the accumulation of amino acids in response to heavy metals could lead to the assumption that the suppressed protein biosynthesis encouraged the accumulation of free amino acids (Khalil, 1997). The accumulation of prolin in the two investigated cyanobacteria could be in part attributable to the relatively high salinity of Kima factory wastewater. In this context, ElShimy and Ismail (2007) have shown that proline was the major intracellular amino acid of $A$. oryzae in response to osmotic stress by salinity. Prolin accumulation under salinity stress may be related to its action as an osmotic regulator or to the regulation of the cellular water structure, which protects against the reduction of the hydration of cytoplasmic constituents (Nakamura, 1979). These results suggested that further comprehensive and detailed investigations concerning the influence of industrial wastewater upon different metabolic activities of the Nile phytoplankton species, particularly cyanobacteria, could be of prime importance. Information obtained from such studies may help in integrated management strategies of the Nile water in Egypt.

\section{REFERENCES}

Abdel-Hammeed, M.S., Kobbai, I., Ali, M.I.A., and Hassan, S. (2002), The effect of pollution stress on the growth and ultra cellular structure of two cyanobacterial species. Proc. Plants and Industrial Pollution. The Egypt. Bot. Soc., Cairo. pp. 17-33.

Abdel-Mawgoud, A.M. (2005), Physiological and ecological studies on the algal flora isolated from soils at Qena regions. M.Sc. Thesis, Fac. of Sci. South Valley Univ., Qena, Egypt. pp. 199.

Angadi, S.B., and Mathad, P. (1994), Effect of chromium and nickel on Scenedesmus quadricauda (Türp.) de Breb. Phykos, 33, 99-103.

Arieli, B., Binder, B., Shahak, Y., and Padan, E. (1989), Sulfide Induction of Synthesis of a Periplasmic Protein in the Cyanobacterium Oscillatoria limnetica. J. Bacteriol., 171, 699-702.

Canizares-Villanueva, R.O., Dominguez, A.R. Cruz, M.S., and Rios-Leal, E. (1995), Chemical composition of cyanobacteria grown in diluted, aerated swine wastewater. Biores. Technol., 51, 111116

Christian, G. (1990), HPLC Tips and Tricks. Great Britain at the Iden Press, Oxford .pp. 608.

Desouky, S.A. (1990), Interactive effects of $\mathrm{Na}^{+}$and $\mathrm{K}^{+}$ on some metabolic activities of Chlorella vulgaris. M.Sc. Thesis, Fac. of Sci. Assiut Univ., Assiut, Egypt. pp. 199.

Durrani F.R., and Khalil, I.A. (1989), Green algae as a protein source in animal feed. Pakistan. J. Sci. indust. Res., 32, 117-119.

El-Ayouty, Y.M., and Ezzat, S.M. (1991), Effect of the herbicide prometryn on the metabolic activity of the Cyanobacterium Nostoc musocorum. Egypt. J. Microbiol., 26, 194-208.

El-Enany, A.E., and Issa, A.A. (2000), Cyanobacteria as a biosorbent of heavy metals in sewage water. Environ. Toxicol. Pharmacol., 8, 95-101. 
El-Naggar, A.H. (1993), Growth and some metabolic activities of Chlorella and Scenedesmus in relation to heavy metal pollution in Gharbia Governorate. Ph. D. Thesis. Bot. Depart., Fac. Sci., Tanta University. pp. 278.

El-Naggar, A.H., Osman, M.E.H., Dyab, M.A., and ElMonhsenawy, E.A. (1999), Cobalt and lead toxicities on Calothrix fusca and Nostoc muscorum. J. Union Arab biol., Cairo. Botany (Physiology and algae)., 7, 421-441.

El-Sheekh, M.M., El-Shouny, W.A., Osman, M.E.H., and El-Gammal, E.W.E. (2005), Growth and heavy metals removal efficiency of Nostoc muscorum and Anabaena subcylindrica in sewage and industrial wastewater effluents. Environ. Toxicol. Pharmacol., 19, 357-365.

El-Shimy, A.A., and Ismail, A.G. (2007), Accumulation of amino acids in Anabaena oryzae in response to sodium chloride salinity. J. Applied Sci. Res., 3, 263266.

Fathi, A.A. (2003), Some metabolic activities in the green alga Scenedesmus bijuga as affected by the insecticide trichlorfon. Protistology., 3, 92-98.

Fernandez-Pinas, F., Mateo, P., and Bonilla, I. (1991), Physiological and structural responses of the cyanobacterium Nostoc UAM 208 to free $\mathrm{Cd}^{2+}$ ion. Plant Physiol., 10, 173:178.

Galal, H.R. (1998), Growth and some metabolic activities of freshwater algae under variable treatments. Ph.D. Thesis, Fac. Sci. Qena. South Valley Univ. Egypt, pp. 328.

Hammouda, O., Gaber, A., and Abdel Raouf, N. (1995), Microalgae and wastewater treatment. Ecotoxicol. Environ. Safety., 31, 205-210.

Hart, B.A. and Scaife, B.D. (1997) Toxicity and bioaccumulation of cadmium in Chlorella pyrenoidosa. Environ. Res., 14, 401-413.

Khalil, Z. (1997), Toxicological response of a cyanobacterium Phormidium fragile to mercury. Water Air Soil Pollut., 98, 179-185.

Kobbia, I.A., Hofner, W., Naguib, M.I., and Ibrahim, Z.K. (1985). Uses of laboratory cultures of some algae to predict heavy metal toxicity VI. Effect of various concentrations of $\mathrm{Cd}, \mathrm{Cr}, \mathrm{Ni}$ and $\mathrm{Zn}$ on the composition of amino acids and soluble proteins in Chlorella fusca. Bull. Fac. Sci., Cairo Univ., 53, 249263.

Kott, Y., and Wachs, A.M. (1964), Amino acid composition of bulk protein of Euglena grown in wastewater. Appl. Microbiol. 12, 292-294.

Laemmli, U.K. (1970), Cleavage of the structural proteins during the assembly of the head of the bacteriophage T4. Nature., 227, 680-685.

Lowry, O.H., Rosebrough, N.J., Farr, L.A., and Randall, R.J. (1951), Protein measurements with the folin phenol reagent. J. Biol. Chem., 193, 265-275.
Mishra, B.B., and Nanda, D.R. (1997), Reclamation with cyanobacteria: toxic effect of mercury contaminated waste soil on biochemical variables. Cytobios., 92, 203-208.

Mohamed, A.A., and Shafea, A.A. (1992), Growth and some metabolic activities of Scenedesmus obliquus cultivated under different $\mathrm{NaCl}$ concentrations. Biol. Plant., 34, 423-430.

Moore, S., and Stein, W. (1948), Photometric ninhydrine method for use in the chromatography of amino acid. From the laboratories of Rockefeller institute for Medical Research, New York. J. Biol. Chem., 176, 367-388.

Nakamura, A.H. (1979), Specific proline accumulation in an acra mutant of Escherichia k12orown in salthypertonic medium. J. Gen. Microbiol., 113, 425427.

Osman. M.E.H., El-Naggar, A.H., El-Sheekh, M.M., and El-Mazally, E.E. (2004), Differential effects of $\mathrm{Co}^{2+}$ and $\mathrm{Ni}^{2+}$ on protein metabolism in Scenedesmus obliquus and Nitzschia perminuta. Environ. Toxicol. pharmacol., 16, 169-178.

Perez-Rama, M., Herrero Lopez, C., AbaldeAlonso, J. and Torres Vaamonde, E. (2001), Class III metallothioneins in response to cadmium toxicity in the marine microalga Tetraselmis suecica (Kylin) Butch. Environ. Toxicol. Chem., 20, 2061-2066.

Poonguzhali, T.V., and Rao, V.N.R. (1998), Response of algae to metal pollution. Phykos, 37, 19-28.

Pringsheim, E.G. (1949), Pure culture of algae, their preparation and maintenance. Cambridge. Univ. 119 pp.

Rai, P.K., Mallick, N., and Rai, L.C. (1994), Effect of $\mathrm{Cu}$ and $\mathrm{Ni}$ on growth, mineral uptake, photosynthesis and enzyme activities of Chlorella vulgaris at different pH values. Biomed. Environ. Sci., 7, 56-67.

Shad, M.A., Ansari, T. M. Pervez, H. Rubab, M, and Mahmood, T. (2002), Changes in sugar, amino acid and mineral contents of leaves of two mango varieties affected by quick decline disease. J. Biol. Sci., 2, 694696.

Shafea, A.A. (1987), Physiological responses of algal cells to sodium chloride salinization with a special reference to proline accumulation. M.Sc. Thesis, Fac. of Sci. Assiut Univ., Assiut, Egypt. pp. 249.

Stein, J.R. (1966), Growth and mating of Gonium pectoral (Volvocales) in defined media. J. Phycol., 2, 23-28.

Strickland, J.D.H. and Parsons, T.R. (1968), A practical handbook of sea water analysis, Bull. Fish. Res. Bd. Canada, 167, 310.

Wong, M.H., and Tam, F.Y. (1984), Sewage sludge for cultivating freshwater algae and the fate of heavy metals at higher trophic organisms. Arch. Hydrobiol., 100, 287-318. 
Wong, P.K., and Chan, K.Y. (1990), Growth and value of Chlorella salina grown on highly saline sewage effluent. Agricul. Ecosys. Environ., 30, 235-250.

Wu, J.T., Chang, S.C., and Chen, K.S. (1995), Enhancement of intracellular praline leveling cells of anacystis nidulans (cyanobacteria) exposed to deleterious concentrations of copper. J. Phycol., 31, 376-379.
Xylaender, M., and Braune, W. (1994), Influence of nickel on the green alga Haematococcus lacustris rostafinski in phases of its life cycle. J. Plant Physiol., 144, 86-93.

Received: October 21, 2010; Revised: December 15, 2010; Accepted: April 11, 2011. 